\title{
単体硫黄の湿式酸化に関する電気化学的考察*
}

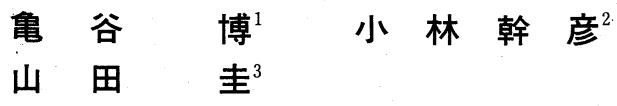

1. 緒言

硫化鉱の湿式酸化には単体硫黄生成反応と硫酸生成反応 の 2 種類がある。熱力学的な立場から見ると一般的な反応 条件では後者が優先するが，実際の反応では通常両者が競 合して進行する。硫化鉱の湿式製鍊としては，これらの反 応はそれぞれ利点, 欠点があるが, いずれにしても反応の 競合を避けいずれか一方の反応のみを進行させることが望 ましいといえる。

前報 (アンモニア性溶液 ${ }^{1)}$ および硫酸酸性溶夜 $\left.{ }^{2)}\right)$ にて 活性硫黄末による $\mathrm{Cu}$ 除去 $(\mathrm{CuS}$ 生成)について報告した。 これらの反応は基本的に硫黄の不均化反応によるものであ り，硫黄の一部がアノード反応により酸化されるのに伴つ て, $\mathrm{Cu}^{2+}$ または $\mathrm{Cu}\left(\mathrm{NH}_{3}\right)_{4}^{2+}$ と $\mathrm{S}$ が反応し $\mathrm{CuS}$ 生成のカy 一ド反応が進行する。

純粋な硫黄は安定で特に酸性溶液中では酸化され難いが, 硫黄表面にCuSが析出すると，これが触媒的に作用し反応 速度を著しく高める。本研究でいう単体硫黄の酸化はこの ように活性化された硫黄の酸化であつて，純粋な硫黄の酸 化ではない。しかし通常の硫化鉱等の湿式酸化にて, 単体 硫黄生成反応により生成した硫黄中には多か扎少なか子不純 物が含まれており,この不純物の中には $\mathrm{CuS}$ と同様な触媒作 用をもつものもあろうということは容易に推定できる。

このような触媒作用は, 従来あまり明確でなかつた硫化 鉱の湿式酸化に扔ける単体硫黄生成反応々硫酸生成反応の 競合について，その原因を考える際に重要な示唆を与える と思われる。

本研究は上記の 2 報告を主体とし, 関連のある 2,3 の報 告をあわせて用い，単体硫黄の酸化について検討した。ま た，関連する報告のなかには確認実験を要するもの，口頭 発表のみのものがあるので, この機会にこれらをまとめて 報告した。

\section{2. 資料および実験}

\section{$2 \cdot 1$ 資 料}

* 1984 年 7 月 16 日受理

1. 正会員 工博 金属材料技術研究所製錬研究部

2. 正会員 金属材料技術研究所製鍊研究部

3. 金属材料技術研究所金属化学研究部
活性硫黄の酸化速度に関しては,“活性硫黄末による銅一 アンモニア錯イオン溶液中の銅の除去”1) および“活性硫 黄末の不均化反応による酸性溶液中の銅の除去”2) を用い た。鉛精鉱の湿式酸化により生成した S の酸化に関しては “酸性塩化物浴中の鉛精鉱の酸化速度に及ぼす懸濁電位の 影響” ${ }^{3)}$ を用い,さらにS 酸化の確認実験を行なつた ( 後 述 $2 \cdot 2)$ 。 $\mathrm{CuS}$ 酸化のアノード反応に関しては“硫酸溶液 中のCuS酸化速度に及ぼす懸濁電位の影響” ${ }^{4)}$ を用いたが, これは口頭発表であるので後述 $2 \cdot 3$ に実験の概要をまとめ た。この逆の $\mathrm{CuS}$ 生成のカソード反応については, 硫黄懸 濁夜を用いた硫化物化電解による $\mathrm{Cu}^{2+}$ の除去 ${ }^{5) 6)}$ を用いた。 その他，関連反応として飯島製鍊所における亜鉛残渣処 理 ${ }^{7) 8)}$ のデータを用いて検討した。

\section{$2 \cdot 2$ 鉊精鉱の酸化残渣中のSの酸化}

$\mathrm{NaCl}$ 溶液を用いた 12 種の鉛精鉱の定電位酸化について は，すでに報告した ${ }^{3)}$ 。この酸化では主反応である $\mathrm{PbS}$ の 酸化 (単体 $S$ 生成酸化) が終了しても, 引続き酸化剂がゆ つくり添加されることから, 第 2 段反応が存在することが 認められた。この第 2 段反応は主としてPbS 酸化にて生成 した単体 Sの酸化であろうと推定されたが，この酸化を確 認するため次の実験を行なつた。

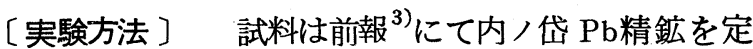
電位酸化した時の反応残渣を集め, これを加熱した $\mathrm{pH}$ 1, $100 \mathrm{~g} / \mathrm{dm}^{3} \mathrm{NaCl}$ 溶液で $\mathrm{PbCl}_{2}$ を溶出させた後洗浄, 乾 燥して準備し $50 \mathrm{~g}$ を用いた。この試料の組成は $\mathrm{Fe}: 3.89 \%$, $\mathrm{Cu}: 2.82 \%, \mathrm{Zn}: 1.72 \%, \mathrm{~Pb}: 0.43 \%, \mathrm{CS}_{2}$ 抽出 $\mathrm{S}: 31.5$ \%である。

溶夜は $0.2 \mathrm{~mol} / \mathrm{dm}^{3}{ }^{\mathrm{a})} \mathrm{NaCl}, 2.0 \mathrm{~g} / \mathrm{dm}^{3}$ 全 $\mathrm{Fe}, \mathrm{pH} 1$ $(\mathrm{HCl}) ， 1.3 \mathrm{dm}^{3}$ を用い, $90^{\circ} \mathrm{C}$, 懸濁電位 ( $\mathrm{SCE}$ ) $0.43 \mathrm{~V}$ にて $\mathrm{KMnO}_{4}$ を電位調節用酸化剤として用いて定電位酸化 を行なつた。反応中，適宜分析用溶液を取り 5 C 洰紙で洰 過後，溶出金属を原子吸光，溶出 Sを I C P 発光分析法で 分析した。

[実験結果] 反応中の $\mathrm{KMnO}_{4}$ 添加量, $\mathrm{SO}_{4}$ 濃度の 变化を Fig.1 Aに示した。 $\mathrm{KMnO}_{4}$ 添加曲線は扰物線に近 いが, $\sqrt{t}$ でプロットすると約 30 時間で彎曲し複雑である。

a） $\mathrm{S}$ の I CP 発光分析のため低 $\mathrm{NaCl}$ 濃度にした。 


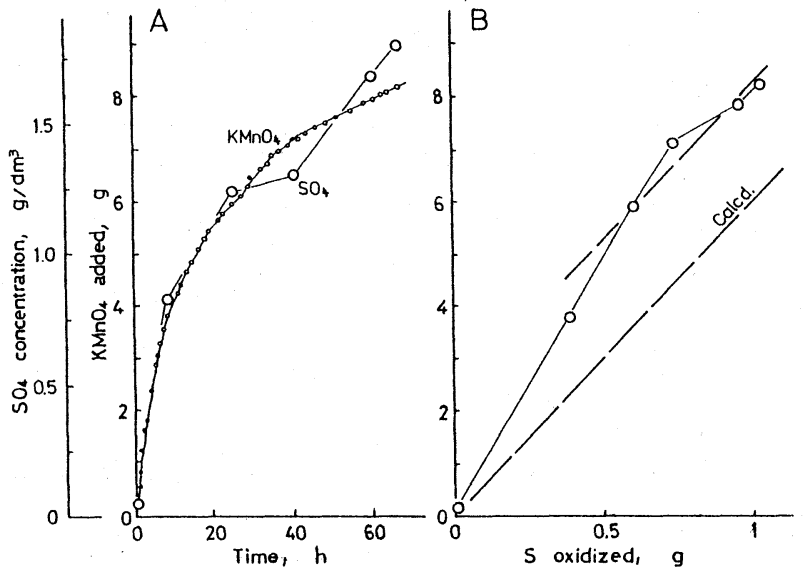

Fig. 1 Results for oxidation of sulphur in oxidation residue of $\mathrm{Pb}$ concentrate at a controlled suspension potential of $0.43 \mathrm{~V}$ $90^{\circ} \mathrm{C}$.

A: Variation of the amount of $\mathrm{KMnO}_{4}$ added and the concentration of $\mathrm{SO}_{4}$ (large circle) with time, B: Correlation between the amount of $\mathrm{KMnO}_{4}$ added and the amount of oxidized sulphur calculated from the concentration increment of $\mathrm{SO}_{4}$. Broken lines: calculated correlation between $\mathrm{S}$ and $\mathrm{KMnO}_{4}$ for $\mathrm{SO}_{4}$ formation.

溶液中の $\mathrm{SO}_{4}$ 濃度の最終值は $1.80 \mathrm{~g} / \mathrm{dm}^{3}$ に達した。 $\mathrm{KMn}$ $\mathrm{O}_{4}$ 添加量と $\mathrm{SO}_{4}$ 濃度より求めた溶出 $\mathrm{S}$ 量の関係をFig. $1 \mathrm{~B}$ に示した。試料中の残存 $\mathrm{Zn}, \mathrm{Cu}$ も多少酸化されるので, 反応の前半は $\mathrm{S}$ 酸化の計算值（破線）より多く $\mathrm{KMnO}_{4}$ が 添加されるが, 後半では実験值はほぼ計算值と平行になり, $\mathrm{S} \rightarrow \mathrm{SO}_{4}$ の酸化が進行していることを示す。40 時間以後 の直線部分より求めた反応速度は $0.0356 \mathrm{~g} / \mathrm{h} \mathrm{KMnO} \mathrm{KM}_{4}$ で あつた。

\section{$2 \cdot 3$ 合成 $\mathrm{CuS}$ の定電位酸化}

$\mathrm{CuS}$ の酸化は CuS 生成の逆反応で, それぞれアノード およびカソード反応の関係にある。ここで合成 $\mathrm{CuS}$ 定電 位酸化についての研究 ${ }^{4)}$ をとめた。

[実験方法] $\mathrm{CuS}$ 試料は $60^{\circ} \mathrm{C}, \mathrm{pH} 2$ に保つた硫酸 銅溶液 $\left(100 \mathrm{~g} / \mathrm{dm}^{3} \mathrm{Cu}, 4 \mathrm{dm}^{3}\right)$ に $\mathrm{H}_{2} \mathrm{~S}$ 吹込み, 生成し た沈殿を沪過, 洗浄後 A r 中で乾燥して作製した。このCuS 試料の粒子径は $0.3 \mu \mathrm{m}$, 比表面積は $42,600 \mathrm{~cm}^{2} / \mathrm{g}$ （空気 透過法による ), 熱電率は $8.3 \mu \mathrm{V} / \mathrm{deg}$ であつた。

この試料 $10 \mathrm{~g} を 100 \mathrm{~g} / \mathrm{dm}^{3} \mathrm{H}_{2} \mathrm{SO}_{4}, 0.1 \mathrm{~mol} / \mathrm{dm}^{3}$ 全 $\mathrm{Fe}, 0.2 \mathrm{~mol} / \mathrm{d} \mathrm{m}^{3} \mathrm{Cu}^{2+}, \mathrm{pH} 0$ の溶液 $1 \mathrm{~d} \mathrm{~m}^{3}$ 中に投入し て, 温度 $90^{\circ}, 60^{\circ}$ および $40^{\circ} \mathrm{C}$, 懸濁電位 ( SCE ) $0.34 \sim$ $0.55 \mathrm{~V}$ にて $\mathrm{KMnO}_{4}$ を電位調節用酸化剂として実験した。

[実験結果] 各電位における $\mathrm{KMnO}_{4}$ 添加量の変化 $\left(90^{\circ} \mathrm{C}\right)$ をFig.2に示した。全体の傾向として, 電位が高 くなると反応曲線は左へ移動し, 反応速度は早くなる。

電位 $0.42 \mathrm{~V}$ 以上の酸化では終了時の $\mathrm{KMnO}_{4}$ 添加量は $6.0 \mathrm{~g}$ でほぼ一定であり,これは単体 $\mathrm{S}$ 生成反応 (理論 $\mathrm{KMnO}_{4}$ 添加量 $6.60 \mathrm{~g}$ ) に対応する。しかし $0.42 \mathrm{~V}$ 以下で は, 電位の低下とともに $\mathrm{KMnO}_{4}$ 添加量は増える。0.36 V では $16.5 \mathrm{~g}$ が添加されても反応は終了せず, $\mathrm{SO}_{4}$ 生成反応
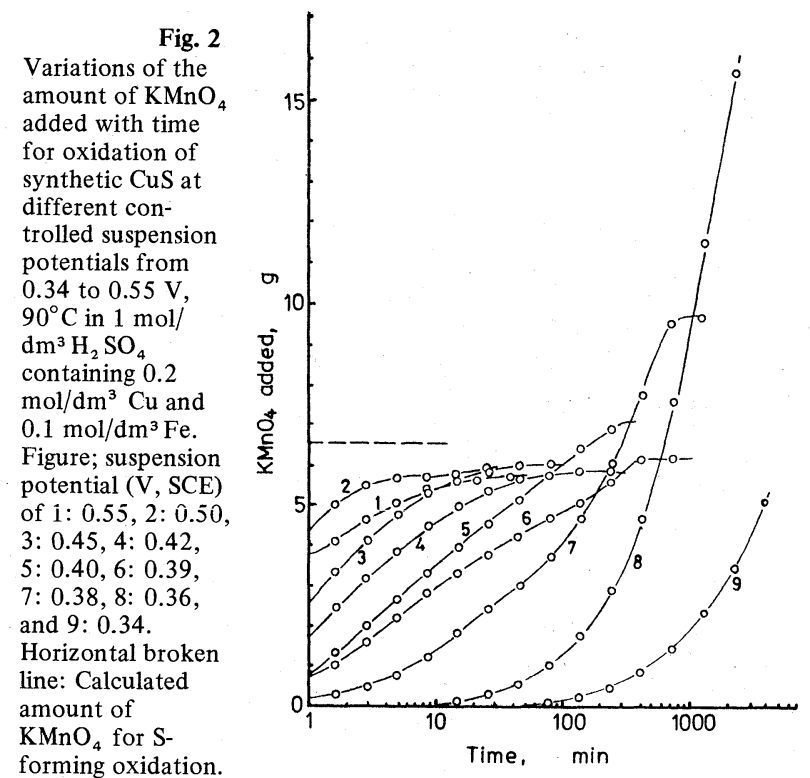

（同 $26.40 \mathrm{~g}$ ) が起こつていると考えられる。

これらの反応は, 実験終了後に残渣を $\mathrm{CS}_{2}$ で抽出して求 めた単体 $S$ 生成率が, 電位 $0.42 \mathrm{~V}$ 以上でほぼ $100 \%, 0.42$

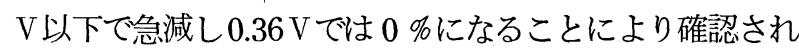
た。

以上をまとめると $90^{\circ} \mathrm{C} て ゙ は$ 電位 $0.42 \mathrm{~V}$ 以上では単体 $\mathrm{S}$ 生 成反応, $0.36 \mathrm{~V}$ 以下で $\mathrm{SO}_{4}$ 生成反応, その中間の電位では 両方の反応 ( あるいは単体 $\mathrm{S}$ 生成反応とそれにより生じた S の一部が酸化される反応 ) がそれぞれ起こることがわか つた。

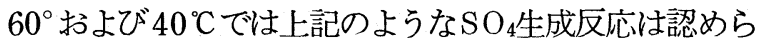
れず，すべて単体 $\mathrm{S}$ 生成反応であつた。またその反応曲線 は $90^{\circ} \mathrm{C}$ 時のように滑らかでなく, 途中で反応が一時的に 停滞するいわゆる 2 段反応の形となるものが見られるなど，

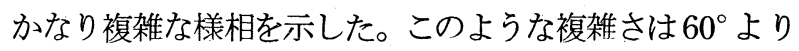
も $40{ }^{\circ} \mathrm{C}$ で一層顕著であつた。これは $\mathrm{CuS}$ 粒子が非常に細 かいため, 乾燥中に微粒子が集まり (凝集) 二次粒子(ア グリゲート）を形成して，これが反応中に分散してゆくな ど，表面状態の微妙な差が大きく作用しているものと考え られる。

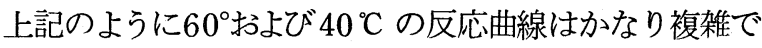



Fig.2 に示した $90^{\circ} \mathrm{C}$ 反応曲線について, それぞれの電


$\mathrm{SO}_{4}$ 生成を仮定した時の理論 $\mathrm{KMnO}_{4}$ 添加量の $\left.26.40 \mathrm{~g}\right)$ を 用いて反応率 $\alpha^{*}$ を計算し， $\alpha^{*}-\log t$ 図上にプロットする と, 全体として一次反応に近い曲線が得られる。

このため近似的に $\alpha^{*}$ が 0.5 に達した時の時間 $\tau_{0.5}$ (半減 期 ) の逆数 $1 / \tau_{0.5}\left(h^{-1}\right)$ により反応速度を代表させた。な お一次反応の場合には, その速度定数 $k_{f}$ と $1 / \tau_{0.5}$ の間に は $k_{f}=0.693 / \tau_{0.5}$ の関係がある。

この $1 / \tau_{0.5}$ と懸濁電位の関係を Fig.3に示した。単体 $S$ 


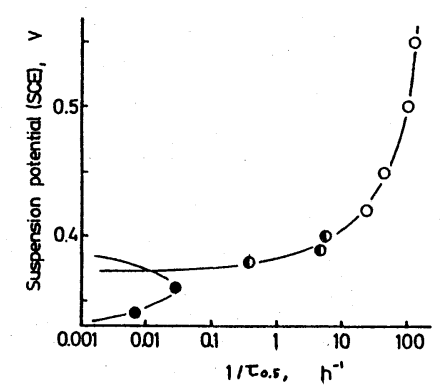

Fig. 3

Dependence of the reaction rate on the suspension potential for oxidation of synthetic CuS. Reaction rate is represented by the reciprocal of the time taken for $50 \%$ oxidation $\tau_{0 . s}$. White circle: S-forming oxidation, black circle: $\mathrm{SO}_{4}$-forming oxidation, and half black circle: mixed oxidation.

生成反応の $0.42 \mathrm{~V}$ 以上では $1 / \tau_{0.5}$ の懸濁電位依存性は比 較的小さく, 懸濁電位の上昇とともにほぼ直線的にゆるや かに増加する。 $0.42 \mathrm{~V}$ 以下で反応速度は急速に減少し, $0.34 \sim 0.36 \mathrm{~V}$ で $\mathrm{SO}_{4}$ 生成反応に変わる。

\section{3. 考察}

この考察では, 懸濁系の反応速度を粒子表面における電 流密度に換算し，これと懸濁電位の関係を調べることによ り単体 S 酸化の電気化学的な検討を行なつた。

\section{$3 \cdot 1$ 活性硫黄のアノード反応}

〔酸性領域〕 $\mathrm{pH} 1 \sim 5.5$ における活性硫黄による $\mathrm{CuS}$ 生成反応(1)式は, 次の $\mathrm{S}$ 酸化のアノード反応(2)式と $\mathrm{CuS}$ 生成のカッード反応(3)式に分けることができる。

$$
\begin{aligned}
& 3 \mathrm{Cu}^{2+}+4 \mathrm{~S}+4 \mathrm{H}_{2} \mathrm{O}=3 \mathrm{CuS}+\mathrm{SO}_{4}^{2-}+8 \mathrm{H}^{+} \ldots \cdots(1) \\
& \mathrm{S}+4 \mathrm{H}_{2} \mathrm{O}=\mathrm{SO}_{4}^{2-}+8 \mathrm{H}^{+}+6 \mathrm{e} \quad \cdots \cdots \cdots \cdots \cdots(2) \\
& \mathrm{E}_{\mathrm{SCE}}=0.112-0.079 \mathrm{pH}+0.010 \log \left(\mathrm{SO}_{4}^{2-}\right) \cdots \cdots(2)^{\prime} \\
& \mathrm{Cu}^{2+}+\mathrm{S}+2 \mathrm{e}=\mathrm{CuS} \quad \cdots \cdots \cdots \cdots \cdots \cdots \cdots \cdots \cdots(3) \\
& \mathrm{E}_{\mathrm{SCE}}=0.376+0.030 \log \left(\mathrm{Cu}^{2+}\right) \ldots \cdots \cdots \cdots \cdots \cdots(3)^{\prime}
\end{aligned}
$$

ここで $\mathrm{E}_{\mathrm{SCE}}$ は飽和カロメル電極基準の計算値 $\left(25^{\circ} \mathrm{C}\right.$,

$298 \mathrm{~K}$ ) である。Sの酸化における中間生成物については 不明の点が多いので, ここでは最終生成物である $\mathrm{SO}_{4}^{2-}$ を 仮定した。 $\mathrm{pH}$ 低いと(4)式により $\mathrm{SO}_{4}^{2-}$ の代りに $\mathrm{HSO}_{4}^{-}$ が生成する $\left(100{ }^{\circ} \mathrm{C}^{\circ} \mathbf{t}^{\text {算値 }}{ }^{9)}\right)$ 。

$$
\log \frac{\left(\mathrm{HSO}_{4}^{-}\right)}{\left(\mathrm{SO}_{4}^{2-}\right)}=-3.20+\mathrm{pH}
$$

硫化物化電解は, 陰極室において(3)式のカソー ド反応のみを電解により進行させる方法であるが, この時の槽電流は不均化反応とほぼ同じ $\mathrm{S}$ 懸濁濃

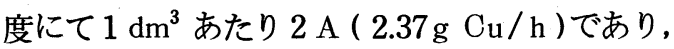
活性硫黄による $\mathrm{CuS}$ 生成の反応速度と比べて著し く大きい值である。従つて(3)式のカソード反応と (2)式のアノード反応を比較すると、アノード反応 の方が速度が小さくこれが律速段階になつている と推定される。

活性硫黄によるCu除去の実験結果より, 隣り合 つた 2 点のCu 濃度の差と時間より $\mathrm{Cu}$ 減少速度 $(\mathrm{g} / \mathrm{h})$ を求め, 電気化学当量 $(1.19 \mathrm{Ah} / \mathrm{g})$ より懸 濁系内の全電流に換算し,この全電流を懸濁した $\mathrm{S}$ 全表面積で割ると粒子表面における電流密度 $\left(\mathrm{A} / \mathrm{cm}^{2}\right)$ が得られる。この計算にて最も誤差を

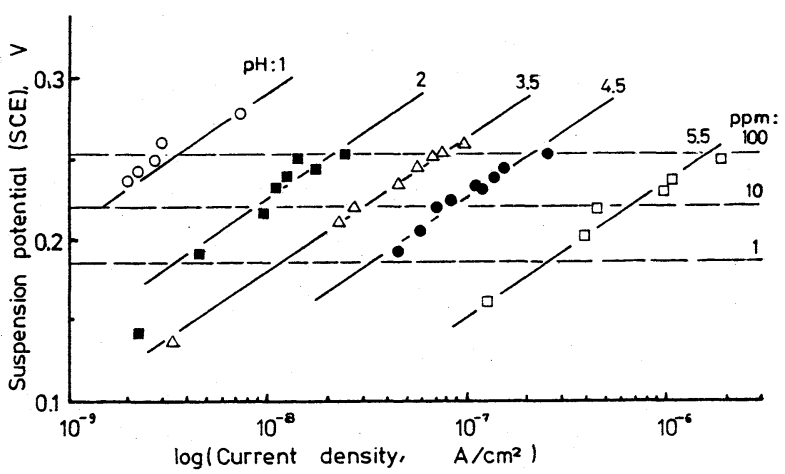

Fig. 4 Correlation between the current density of anodic reaction (see text) and the suspension potential for oxidation of sulphur in acidic solution at $90^{\circ} \mathrm{C}$.

Horizontal broken line: Suspension potential for different $\mathrm{Cu}$ concentrations in $\mathrm{ppm}\left(10^{-3} \mathrm{~g} / \mathrm{dm}^{3}\right)$.

生じ易いのはS S 全表面積であるが, ここでは比表面積と

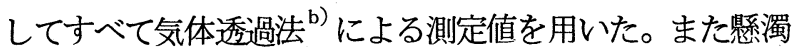
電位は試料採取時の読取值の平均値を用いた。このように して酸性領域におけるアノード反応の電流密度 $i$ と懸濁電 位 $(\mathrm{SCE}) E_{m}$ の関係を調べたのがFig.4である。

同図より明らかなように測定点は $\mathrm{pH}$ 別にほぼ同じ勾配 の直線に沿つて並んでいる。同図ではこの勾配の平均 0.083 を用いて各直線を平行に引いた。また水平の破線は, $\mathrm{Cu}^{2+}$ 濃度が 100,10 および $1 \mathrm{ppm}$ の時の懸濁電位を示し たものである。

$i$ とHの関係を求めるために各 $\mathrm{pH}$ にて 0.24 および $0.18 \mathrm{~V}$ の時の $i$ を読み取り,これと $\mathrm{p} \mathrm{H}$ との関係を調べた のがFig.5 Aである。図中の曲線は $\mathrm{pH} 1$ および 5.5 付近 で勾配 1 の直線（破線）になり，これらの線の間で彎曲し ている。この彎曲の中心点は約 $\mathrm{pH} 3$ で(4)式の $\mathrm{pH} 3.2$ とほ ぼ一致する。これらの曲線の形は前報 に2 における $\mathrm{pH}$ と反 応速度定数 $k$ の関係 (Fig.11) と全く同じであり, $k$ と $i$
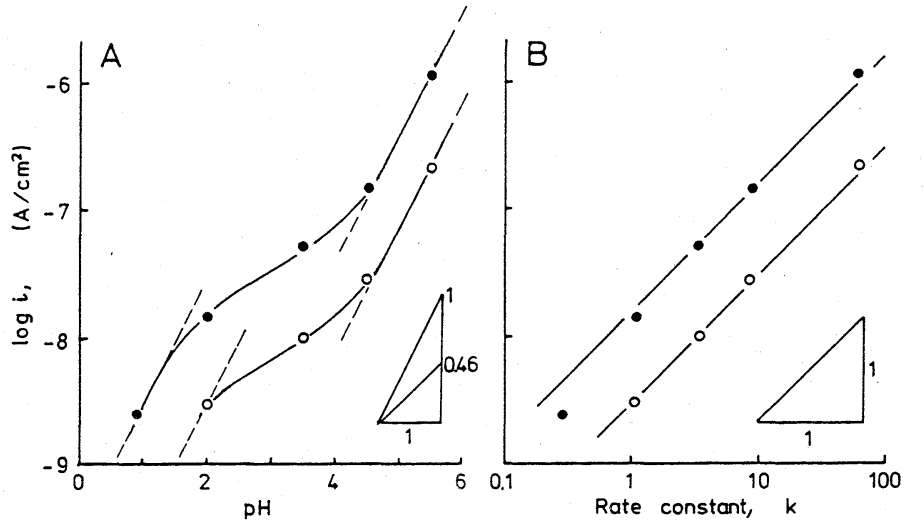

Fig. 5 Correlations between the current density for anodic reaction and $\mathrm{pH}$ and between that and the rate constant for oxidation of sulphur at suspension potentials.

A: Correlations between the current density and $\mathrm{pH}, \mathrm{B}$ : Correlations between the current density and the rate constant taken from previous study 2 ). White circle: $0.18 \mathrm{~V}$ and black circle: $0.24 \mathrm{~V}$.

b ) 島津粉体比表面積測定装置 SS -100 
の間に一定の関係があることが推定された。この関係を調 べたのがFig.5 Bで， $k$ と $i$ 間に比例関係があり,これ より次式が得られた。

$$
\log k=\log i+10.65-11.83 E_{m}
$$

ここで $E_{m}$ は懸濁電位である。

Fig.5で得られた関係を式で表わすと, 次の電極反応の 一般近似式になる。

$$
i=\text { const. }\left[\mathrm{H}^{+}\right]^{-m} \exp \left\{\frac{0.87 F}{R T}\left(E_{m}-E_{0}\right)\right\} \cdots(6)
$$

ここで $\left[\mathrm{H}^{+}\right]$は $\mathrm{H}^{+}$濃度，mは $\mathrm{pH} よ り ~ 1 〜 0.46$ の值を とる定数, 係数 0.87 は透過係数および反応に与る電子の数 の積で, $E_{o}$ は平衡電極電位である。

さて電極反応の速度式は近似的に次式で表わされる ${ }^{10)}$ 。

$$
\begin{aligned}
& I=n F A k\left\{C_{R} \exp \left[\frac{(1-\alpha) n F}{R T}\left(E-E^{o^{\prime}}\right)\right]\right. \\
&\left.-C_{o} \exp \left[-\frac{\alpha n F}{R T}\left(E-E^{o^{\prime}}\right)\right]\right\}
\end{aligned}
$$

ここで $I$ : 電流, $A$ : 電極表面積, $C_{R}, C_{o}$ : それぞれ電極 表面における還元体およひ酸化体の濃度, $k$ : 標準速度定 数, $E^{0^{\prime}}$ : 濃度標準電位, $E$ : 電極電位である。(7)式にて 大カッコ内の第 1 項はアノード反応による項, 第 2 項はカ ソード反応による項を表わしているが, $\left|E-E^{0^{\prime}}\right|$ が充分 に大きく逆反応を無視できる場合はいずれか一方の項を省 略できる。

第 2 項を省略した時の(7)式と(6)式とはその形はほぼ一致 するが，次の点で式の持つ意味が異なる。

(i) 電極反応の理論では, $E^{0^{\prime}}$ は電極反応の平衡電位で, 外部からの印加電生により $E-E^{0^{\prime}}$ の過電圧が生じる。これ に対して(6)式の $E_{o}, E_{m}$ はそれぞれ懸濁粒子の電位および 溶液の酸化還元電位である。前者は直接測定することは不 可能であるが，大体平衡電極電位に近いと推定される。 $E_{m}$ - $E_{0}$ は通常の過電圧とは意味は異なるが, 反応の駆動力と 考えると共通している。

(ii）本研究におけるアノード反応およびカソード反応は, 粒子表面のそれぞれアノード活性点およびカソード活性点 で進行し, 電子はアノード活性点からカソード活性点へ移 動する。これに対して通常の電極反応では電子は電極から 溶液へ，あるいは溶液から電極へと移動する。従つて単に 電子の移動数を全粒子表面積で割つただけでは, 通常用い られている意味での電流密度は求められないが, これも単 位面積あたりの反応速度と考えると共通している。

以上のように各記号は通常の意味とはやや異なるが，見 方を変えると共通した概念を持つており，(6)式と(7)式は同 列に取扱うことができる。さらに一般の腐食反応は電気化 学的に見て,アノードおよびカソード反応に分割して電極 反応として取扱うことができることから考えても，本研究 における不均化反応を電極反応として速度式を適用するこ とは妥当と思われる。

ここで電極として考えている活性硫黄末は熱電率が $8 \mu$ $\mathrm{V} / \operatorname{deg}$ であり ${ }^{2)}$, 值は小さいが $\mathrm{p}$ 型半導体と考えられるの で, 半導体電極として取扱う必要がある。半導体電極につ いては多くの研究 ${ }^{11) ~ 14)}$, 成書 ${ }^{15)}$ があるが, 本研究のよう にS 表面に薄く付着したCuSが, 半導体電極としてどのよ うにふるまうかは明らかでない。例えば, 半導体電極が溶 液と接した時に, 界面から電極内部に生じる空間電荷層の 厚さは, $\mathrm{ZnSe}$ で約 $1 \mu \mathrm{m}$ と推算されている ${ }^{12)}$ が, 本研究 で用いた活性硫黄末表面の $\mathrm{CuS}$ 層の厚さは, $13 \% \mathrm{Cu}$ のも のでも約 $0.3 \mu \mathrm{m}$ と見積られる。さらに抵抗は $\mathrm{Cu}$ 含有率 5 $\%$ 以上は約 $10 \Omega$ で定であるが, 一方 $\mathrm{H}_{2} \mathrm{~S}$ 沈殿法で作つ

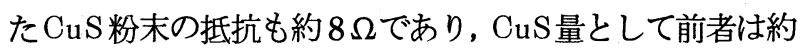
20分の 1 であるにもかかわらず抵抗值はほぼ同じになる。 熱電率の值も両者はほぼ $8 \mu \mathrm{V} / \mathrm{deg}$ で一致するが活性硫黄 末の場合, 単体 $\mathrm{S}$ に近い部分は $\mathrm{S}$ 過利になり, したがつて 大きい值の $\mathrm{p}$ 型になつていることも考えられる。

以上のように半導体電極は極めて微妙に性質が変わるの で，一般的な半導体電極の理論をそのまま適用するのは困 難と考えられる。

活性硫黄末表面のアノードおよびカソード活性点の模式 図をFig. 6 に示した。S表面のCuS 層には酸化による Sの 除去, および(1)式による $4 \mathrm{~S} \rightarrow 3 \mathrm{CuS}$ 変化により体積が $0.2 \%$ 収縮するため, $\mathrm{CuS}$ 層の厚みの薄い所あるいは割れ 目と, 厚い所ができる。 CuS中の $\mathrm{Cu}^{2+}$ および $\mathrm{S}^{2-}$ のイオン 半径はそれぞれ $0.76 \times 10^{-8}$ および $1.70 \times 10^{-8} \mathrm{~cm}$ であるた め, $\mathrm{CuS}$ 層を拡散するイオンは $\mathrm{Cu}^{2+}$ と推定される。従つて CuS層の厚い所ではS の酸化は進行せず主に割れ目の所で $\mathrm{S}$ の酸化が起こる。これをアノード活性点と考えると, カ ソード活性点は CuS 層の厚い所に存在する。

カソード活性点では $\mathrm{Cu}^{2+}$ が内部に拡散し, そのあとに溶 液中の $\mathrm{Cu}^{2+}$ が入る。この拡散した $\mathrm{Cu}^{2+}$ は $\mathrm{CuS}-\mathrm{S}$ 界面に て次式により CuSを生成する。

$$
\mathrm{Cu}^{2+}+\mathrm{S}=\mathrm{CuS}+2 \mathrm{~h}^{+}
$$

ここで $\mathrm{h}^{+}$は正孔である。このような反応について，e を用 いて表す(3)式と $\mathrm{h}^{+}$を用いて表す(8)式があるが, $\mathrm{p}$ 型半導体 ではキャリャーとして正孔の方がより適切であろう。

この正孔は電導性のよいCuS中を迅速に移動してアノー ド活性点にて S 酸化に与る。一般にCdS, Znse などの

Cathodic active site O Anodic active site

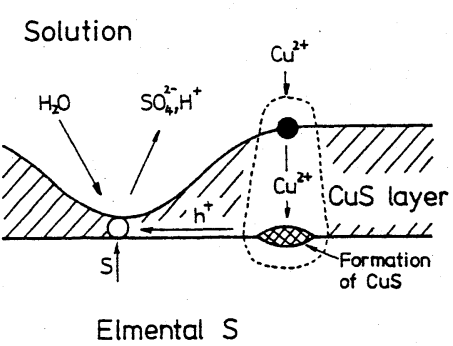

Fig. 6

Schematic illustration of the disproportionation reaction showing active sites on the CuS layer covering the surface of sulphur. 


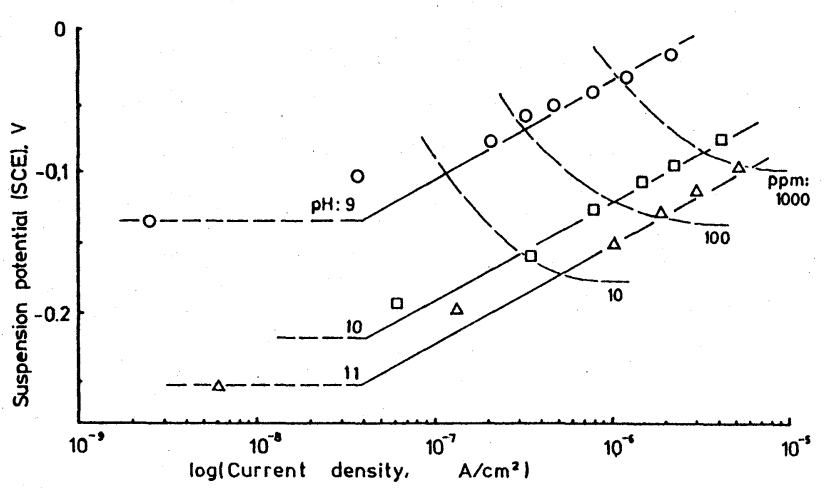

Fig. 7 Correlation between the current density of anodic reaction (see text) and the suspension potential for oxidation of sulphur in ammonia alkaline solution at $30^{\circ} \mathrm{C}$.

Broken curve: Variation of suspension potential for different $\mathrm{Cu}$ concentrations in $\mathrm{ppm}\left(10^{-3} \mathrm{~g} / \mathrm{dm}^{3}\right)$.

アノード反応 ( 溶解)では正孔が直接に反応に関与する ${ }^{16}$ 。 これらの反応から類推すると $\mathrm{SO}_{4}^{2-}$ 生成を仮定して $\mathrm{S}$ の酸 化は次式で表される。

$$
\mathrm{S}+4 \mathrm{H}_{2} \mathrm{O}+6 \mathrm{~h}^{+}=\mathrm{SO}_{4}^{2-}+8 \mathrm{H}^{+}
$$

アノード活性点については, 割れ目に ある単体 Sの表面, その表面の周囲 $(\mathrm{CuS}$ の縁)およびごく薄いCuS 層の表面が考 えられるが，いずれにせよ正孔の供給 (あるいは電子の流出 ) を考える必要が あろう。

カソード活性点の電位は $\mathrm{Cu}^{2+} / \mathrm{CuS} \mathrm{,}$ $\left(3^{\prime}\right)$ 式の電位, アノード活性点の電位は 具体的には不明であるが $\mathrm{S}$ の酸化, 即ち $\mathrm{SO}_{4}^{2-}$ 生成を仮定すると (2') 式の電位と 考元られ，これがアノード分極されて(6) 式の $E_{m}-E_{0}$ に相当すると考えられる。

仮りに $\left(2^{\prime}\right)$ 式を用い, $\mathrm{pH} 5.5,\left(\mathrm{SO}_{4}^{2-}\right)$ : $0.5 \mathrm{~mol} / \mathrm{dm}^{3}$ とすると $\mathrm{E}_{\mathrm{SCE}}$ はー0.326 Vとなる。これを $E_{0}$ と仮定して $E_{m}=$ $0.22 \mathrm{~V}$ にて $i=6.8 \times 10^{-7} \mathrm{~A} / \mathrm{cm}^{2}$ を用い， (6)式より交換電流密度を求めると $1.7 \times$ $10^{-13} \mathrm{~A} / \mathrm{cm}^{2}$ が得られる。低い值の交換 電流密度として, $\mathrm{Pt}$ 上の $\mathrm{O}_{2}$ について 9 $\times 10^{-12} \mathrm{~A} / \mathrm{cm}^{2}$ の報告 ${ }^{17)}$ があるので, 上 記の推定値はオーダーとして妥当な値で あろう。

[アンモニア・アルカリ領域 ] $\mathrm{pH}$ 9〜11 における $\mathrm{Cu}\left(\mathrm{NH}_{3}\right)_{4}^{2+}$ からの $\mathrm{CuS}$ の生成反応は, $\mathrm{S}$ 酸化の中間生成物を $\mathrm{S}_{2} \mathrm{O}_{3}^{2-}$ と仮定すると ${ }^{1)}(10)$ 式になり，この 反応はさらにアノード反応(11)式およびカ ソード反応(12式に分けることができる。

$$
\begin{aligned}
& 2 \mathrm{Cu}\left(\mathrm{NH}_{3}\right)_{4}^{2+}+4 \mathrm{~S}+3 \mathrm{H}_{2} \mathrm{O}=2 \mathrm{CuS}+8 \mathrm{NH}_{3} \\
& +\mathrm{S}_{2} \mathrm{O}_{3}^{2-}+6 \mathrm{H}^{+} \text {........................10) } \\
& 2 \mathrm{~S}+3 \mathrm{H}_{2} \mathrm{O}=\mathrm{S}_{2} \mathrm{O}_{3}^{2-}+6 \mathrm{H}^{+}+4 \mathrm{e} \quad \cdots \cdots \cdots \cdots \cdots(11) \\
& \mathrm{E}_{\mathrm{SCE}}=0.221-0.089 \mathrm{pH}+0.015 \log \left(\mathrm{S}_{2} \mathrm{O}_{3}^{2-}\right) \cdots \cdots(11)^{\prime} \\
& \mathrm{Cu}\left(\mathrm{NH}_{3}\right)_{4}^{2+}+\mathrm{S}+2 \mathrm{e}=\mathrm{CuS}+4 \mathrm{NH}_{3} \quad \cdots \cdots \cdots . . .(12) \\
& \mathrm{E}_{\mathrm{SCE}}=-0.028+0.030 \log \left(\mathrm{Cu}\left(\mathrm{NH}_{3}\right)_{4}^{2+}\right) \\
& -0.118 \log \left(\mathrm{NH}_{3}\right)
\end{aligned}
$$

前記酸性領域と同様にアノード反応の電流密度を求め, これと懸濁電位の関係を調べた結果をFig.7 に示した。 Fig.5と同じように測定点は温度, $\mathrm{pH}$ 別にほぼ同じ勾配の 直線に沿つて並んでいるが，この勾配は温度によりわずか ずつ異なる。またこの系は $\mathrm{Cu}\left(\mathrm{NH}_{3}\right)_{4}^{2+}-\mathrm{NH}_{3}-\mathrm{NH}_{4}{ }^{+}$間の 平衡があるため, $\mathrm{pH} 10$ と 11 の直線の間隔が狭くなり, $\mathrm{Cu}$ 分析濃度と電位の関係を示す破線は $\mathrm{pH} 10$ 付近で彎曲し, より高い $\mathrm{pH}$ で水平に近くなる。

$30^{\circ} \mathrm{C}$ にて懸濁電位と $i$ の関係をまとめると, $\mathrm{pH} 9 \sim 10$

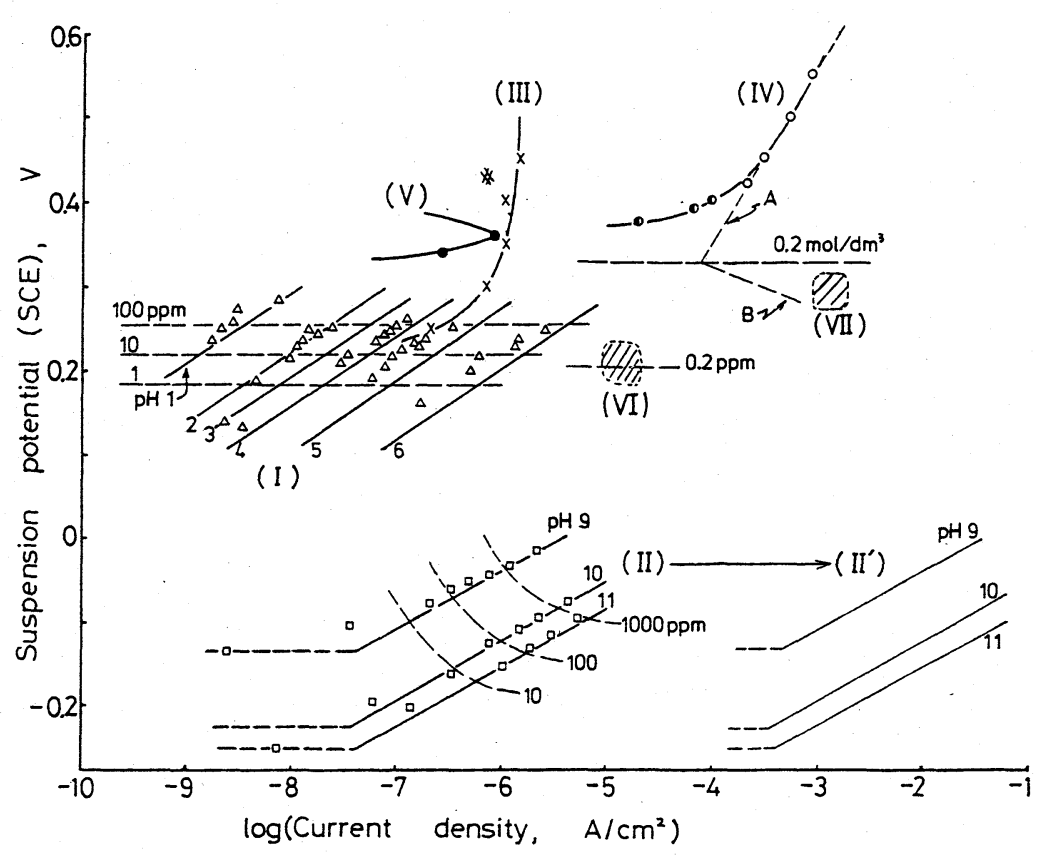

Fig. 8 Comparison of various anodic reactions (oxidation of $S$ ) and cathodic reactions (formation of $\mathrm{CuS}$ ) showing the variation of current density with the suspension potential.

I: Anodic reaction for disproportionation reaction of activated sulphur in acidic solution, $90^{\circ} \mathrm{C}$ (refer to Fig. 4), II: Anodic reaction for disproportionation reaction of activated sulphur in ammonia alkaline solution, $30^{\circ} \mathrm{C}$ (refer to Fig. 7), II': Calculated current density at $90^{\circ} \mathrm{C}$ for II (activation energy: 143 $\mathrm{kJ} / \mathrm{mol}$ ), III: Anodic reaction for oxidation of sulphur in oxidation residue of $\mathrm{Pb}$ concentrate, \#: data from Fig. $1,90^{\circ} \mathrm{C}$, and $\mathrm{X}$ : data from oxidation of $\mathrm{Pb}$ concentrate at controlled suspensionpotentials, $70^{\circ} \mathrm{C} 3$ ), IV: Anodic reaction for oxidation of synthetic $\mathrm{CuS}, 90^{\circ} \mathrm{C}$ (white circle: S-forming oxidation), Broken line A: Tafel correlation for the anodic reaction and Broken line B: tentative Tafel correlation for cathodic reaction derived from the anodic reaction, data from Fig. 3, V: Anodic reaction for oxidation of synthetic $\mathrm{CuS}$, $90^{\circ} \mathrm{C}$ (black circle: $\mathrm{SO}_{4}$-forming oxidation), data from Fig. 3, VI: Cathodic reaction for sulphidising suspension electrolysis, room temperature, data for $0.2 \mathrm{ppm} \mathrm{Cu} 5$ ), VII: Comparison of data for precipitation of $\mathrm{CuS}$ with $\mathrm{S}$ under $\mathrm{SO}_{2}$ pressure, $105^{\circ} \mathrm{C}^{7}$ ), see eq.(17).

Broken line and curve with figure: Variation of suspension potential for different $\mathrm{Cu}$ concentrations in $\mathrm{ppm}$ under respective experimental condition. 
および10～11にてそれぞれ(13)およ゙(14式が得られる。

$E_{m}=1.253-0.086 \mathrm{pH}+0.069 \log i \quad \cdots \cdots \cdots(13)$

$E_{m}=0.593-0.030 \mathrm{pH}+0.069 \log i \quad \cdots \cdots \cdots(14)$

これらの式を変形すると(6)式と同じ形で, 0.87 の係数も 同じになる。ただし $\mathrm{H}^{+}$濃度依存性は異なり, $\mathrm{pH} 9$ ～10に て $m=1.24, \mathrm{pH} 10 \sim 11$ にて $m=0.43$ になる。

[総括図] Fig.4，7を含めより幅の広い検討を行 なうための総括図をFig.8に示した。同図の I はFig.4,

II はFig. 7 を示したものである。後者にて $20^{\circ} \sim 40^{\circ} \mathrm{C}$ の活 性化エネルギー $143 \mathrm{KJ} / \mathrm{mol}$ を用いて仮りに $90^{\circ} \mathrm{C}$ の反応 を推定すると，図中の II が得られる。

\section{$3 \cdot 2$ 鉊精鉱酸化残椬中の硫黄の酸化}

$2 \cdot 2$ の実験で得た $\mathrm{KMnO}_{4}$ 添加速度を用い, $50 \mathrm{~g}$ 中 31.5 $\%$ \% ( 比表面積 $3 \times 10^{4} \mathrm{~cm}^{2} / \mathrm{g}$ を仮定 ) についての $i$ を 求めて, Fig.8のIIの部分に\#印で示した。

また前報 ${ }^{3)} の \mathrm{~A}$ ( 内ノ岱) 精鉱の定電位酸化の実験結果 を用い, $\mathrm{PbS}$ 酸化後の第 2 段反応について $\mathrm{KMnO}_{4}$ 添加速 度より $i$ を求め, これと懸濁電位の関係を同図中に $\times$ 印で 示した。両者の結果はほぼ一致している。

実験条件 $\left(\mathrm{pH} 1,70^{\circ} \mathrm{C}\right)$ が異るので他のデータと直接比

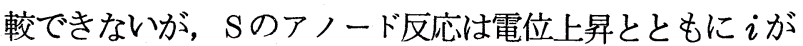
増大したのち，0.3〜0.4V以上で飽和值に達すると推定さ れる。 $\mathrm{Pb}$ 精鉱は一般に $\mathrm{Ag}$ 含有量が高い特徵 (内ノ岱: 約 $0.1 \%)$ があり, $\mathrm{Ag}_{2} \mathrm{~S}$ が $\mathrm{CuS}$ と同様に触媒として作用す ることも考えられる。

\section{$3 \cdot 3$ 合成CuSのアノードおよびカソード反応}

$2 \cdot 3$ の合成 $\mathrm{CuS}$ の定電位酸化の結果より, $\mathrm{KMnO}_{4}$ 添加 速度から求めた $i$ と懸濁電位の関係を Fig. $8, \mathrm{~N}$ の部分に 示した。 $0.42 \mathrm{~V}$ 以上の単体 $\mathrm{S}$ 生成反応 (アノード反応) は ほぼ直線になり,この直線は $E_{0}$ を $0.33 \mathrm{~V}$ として次式で与 えられる。

$$
i=7.9 \times 10^{-5} \exp \left\{\frac{0.34 F}{R T}\left(E_{m}-0.33\right)\right\}
$$

この反応に与る電子の数は不明であるが, 仮りにこれを 1 とし, カソード反応の透過係数を 0.66 とした時の電位と $i$ の関係を破線 $B$ で示した。このカソード反応は, 電位が 下がると急速に増大する。

\section{$3 \cdot 4$ 低電位における $\mathrm{SO}_{4}$ 生成反応}

$2 \cdot 3$ にて認められた $\mathrm{SO}_{4}$ 生成反応をFig.8，Vに示した。 この反応は, 平衡電位よりわずかに上で単体 $\mathrm{S}$ 生成反応の 速度が極めて遅い所で進行し， $0.42 \mathrm{~V}$ より高く単体 $\mathrm{S}$ 生成 反応が短時間で終了する時には認められない(あるいは実

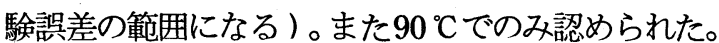

この $\mathrm{SO}_{4}$ 生成反応は, 四の曲線とオーダーが一致し, 単 体 $\mathrm{S}$ のアノード反応 ( I の部分) の上にある ( $\mathrm{Cu}$ 濃度が異 なる)。従つて高 $\mathrm{Cu}$ 濃度にて $\mathrm{Cu}^{2+} / \mathrm{CuS}$ 平衡電位よりわず かに高い電位で(2)式のアノード反応が進行して $\mathrm{SO}_{4}$ が生 成するが, 電位が高くなると単体 $\mathrm{S}$ 生成反応が優先し, か
つ $\mathrm{CuS}$ がS 酸化の触媒的な機能を失うのであろう。60に てこの $\mathrm{SO}_{4}$ 生成反応が認められないことは, 単体 $\mathrm{S}$ 酸化反 応の活性化エネルギーが大きい $(104 \mathrm{~kJ} / \mathrm{mol})$ ことによ ると推定される。これを逆に高温側に外挿すれば, $\mathrm{SO}_{4}$ 生 成反応は $\mathrm{pH} 0,174{ }^{\circ} \mathrm{C}$ に CuSの酸化（Nの曲線, 活性化 エネルギー29.7 kJ / mol ) と同じになる。

$3 \cdot 5$ 硫化物化電解におけるカソード反応

硫化物化電解は, 隔膜で区分した陰極室にて次のカソー ド反応を利用して溶液中の親硫黄元素を硫化物として析出, 除去する電解法である ( $\mathrm{M}: 2$ 価金属)。

$$
\mathrm{M}^{2+}+\mathrm{S}+2 \mathrm{e}=\mathrm{MS}
$$

この電解においても純 $\mathrm{S}$ 粒子の表面では反応が遅く， S 表面に若干のCuSが析出すると槽電流を大きくすることが でき, 同時に電解が安定する。

$62 \mathrm{dm}^{3}$ の陰極室容積をもつヒレ付型電解槽の脱銅電解 ( 室温 $)^{5)}$ にて, 槽電流 $120 \mathrm{~A}, 0.2 \mathrm{ppm} \mathrm{Cu}$ の時の $i$ と懸 濁電位の関係をFig.8，Vの斜影区域で示した。なお，上 記の槽電流は最大值ではなく，技術的な向上によりさらに 増大できると思われる。

\section{3・6 飯島製鍊所における浸出之脱銅}

飯島製鍊所における亜鉛残渣は硫黄末とともに電解尾液 でリパルプし，オートクレーブを用い $105{ }^{\circ} \mathrm{C}$ で $\mathrm{SO}_{2}$ を吹 込みながら処理し, 浸出と脱銅 (ただし一部は残存する ) を同時に行なつている ${ }^{7)}$ 。この $\mathrm{SO}_{2}$ は還元剂として残渣中 の 3 価 $\mathrm{Fe}$ の溶解を容易にするとともに, 次式により $\mathrm{CuS}$ 生成にも利用されている。

$$
\mathrm{Cu}^{2+}+\mathrm{S}+\mathrm{SO}_{2}+2 \mathrm{H}_{2} \mathrm{O}=\mathrm{CuS}+\mathrm{HSO}_{4}^{-}+3 \mathrm{H}^{+} \quad \cdots(17)
$$

この時のアノード反応は $\mathrm{SO}_{2}$ の酸化であるが, 類似反応 ( CuS生成)として比較してみた。

昭和 49 年における操業成績 ${ }^{18)}$ より $\mathrm{Cu}$ 処理速度を求め, 当量の $\mathrm{S}$ (比表面積 $1.5 \times 10^{3} \mathrm{~cm}^{2} / \mathrm{g}$ ) が添加されたと仮定 すると $i=1.1 \times 10^{-3} \mathrm{~A} / \mathrm{cm}^{2}$ が得られた。Cu濃度を約 100 ppm と仮定して, この值をFig.8，VII斜影区域で示した。 $\mathrm{S}$ 酸化のアノード反応 $\mathrm{I}$ の $\mathrm{pH} 1$ と比較すると, $\mathrm{SO}_{2}$ 酸化 のアノード反応はおよそ $10^{5}$ 倍と推定された。

\section{4. 結論}

活性硫黄末による銅除去 (アンモニア性溶液 $\left(30^{\circ} \mathrm{C}\right)$ お よび酸性溶液 $\left(90^{\circ} \mathrm{C}\right)$ ) におうす不均化反応, 鉛精鉱を定 電位酸化した残渣中の硫黄の酸化 $\left(70^{\circ} \mathrm{C}\right)$ とその追加実験 $\left(90^{\circ} \mathrm{C}\right)$, 合成 $\mathrm{CuS}$ の定電位酸化 $\left(90^{\circ} \mathrm{C}\right)$ ，硫化物化電解 ( 室温 )，および飯島製鍊所における浸出と脱銅 $\left(105^{\circ} \mathrm{C}\right)$ についての報告を用い, 硫黄懸濁系における S酸化のアノ ードおよび $\mathrm{CuS}$ 生成のカソード反応について検討した。い ずれも反応速度を電流に換算し，これを全 $\mathrm{S}$ 表面積で割つ て $\mathrm{S}$ 表面における電流密度 $i$ を求め, これと懸濁電位 $E_{m}$ ( Pt vs. SCE)の関係を調べた。

活性硫黄の不均化反応では, 硫化物化電解のカソード反 
応の電流密度が充分に大きいことから，S酸化のアノード 反応が律速と推定される。このアノード反応の電流密度の 懸濁電位依存性は次の実験式で表わされる。

$$
i=\mathrm{const} .\left[\mathrm{H}^{+}\right]^{-m} \exp \left\{\frac{0.87 F}{R T}\left(E_{m}-E_{0}\right)\right\}
$$

ここで $m: \mathrm{pH} よ り$ 異なる定数, $E_{0}$ : 平衡電極電位である。 鉛精鉱の酸化残渣中の硫黄の酸化反応より求めたアノー ド反応の電流密度は, $0.3 \sim 0.4 \mathrm{~V}$ 以上で一定の飽和値に達 することがわかつた。

合成 $\mathrm{CuS}$ の定電位酸化において, 懸濁電位 $0.42 \mathrm{~V}$ 以上で は $\mathrm{S}$ 生成で $E_{m}-\log i$ 図上でほぼ直線で表わされる。 $0.36 \mathrm{~V}$ 以下は $\mathrm{SO}_{4}$ 生成反応で, その電流密度はほぼ鉛精鉱酸化残 渣のアノード反応の電流密度と同じオーダーになつた。以 上の結果から, 硫化物の酸化の際の $\mathrm{S}$ 生成反応と $\mathrm{SO}_{4}$ 生成 反応の競合について，この競合に及ぼす温度や $\mathrm{pH}$ の影響 を説明することができた。

飯島製鍊所におうる単体 $\mathrm{S}$ による脱銅は, $\mathrm{SO}_{2}$ を還元剂 とする点でやや異なる。推定された電流密度は，S 酸化の アノード反応の電流密度のおよそ $10^{5}$ 倍であつた。

$$
\text { 参考文 献 }
$$

1）亀谷 博·後藤建次郎·広瀬文雄：日本鈗業会誌, 101 (1985),
$313 \sim 319$

2）小林幹彦・山田 圭·亀谷 博: 日本鉱業会誌, 101 (1985), $482 \sim 488$

3）亀谷 博：日本鉱業会誌，99（1983）, 117～122

4）小林幹彦・亀谷 博: 昭和 57 年日本鉱業会春季大会発表, 要旨集 $277 \sim 278$, 昭和 57 年 4 月

5）亀谷 博, 三間達也, 小林幹彦: 日本鉱業会誌, 99 (1983), 485 $\sim 490$

6）亀谷 博 ·三間達也: 昭和 54 年日本釷業会春季大会発表, 要旨集 $395 \sim 396$, 昭和 54 年 4 月

7）澤口藤雄 ·恵美元明：日本鉱業会誌，97（1981）, 685 691

8）山田富三，日野 隆 : 特公昭 56-9220（昭和 56 年 2 月）

9）岡部泰一郎 - 增子昇 : 製錬硫黄の新しい固定法 II , (新しい硫黄固 定法研究委員会 $), 14 ，(1981)$ ，日本釷業会

10） H.H.Bauer（玉虫伶太，佐藤 弦訳）：電極反応，29，(1976）， 東京化学同人

11) H.Gerischer: Z.Phys. Chem. N.F. 27 (1961), 48 79

12) Richard Williams: J.Electrochem. Soc., 114 (1967), $1173 \sim 1179$

13) L.D. Locker and P.L.deBruyn: J.Electrochem.Soc., 116 (1969) 1659 1665

14) Richard Williams: J.Chem. Phys., 32 (1960), 1504 1514

15）玉虫伶太，他：電極反応の基礎，(1973）, 共立出版

16) 同 上, 79

17) N.Tanaka and R. Tamamushi : Electrochem. Acta.9 (1954), 963 989

18）私信

\section{Electrochemical Aspects of Aqueous Oxidation of Elemental Sulphur Activated by Cupric Sulphide}

\section{by Hiroshi KAMETANI ${ }^{1}$, Mikihiko KOBAYASHI ${ }^{2}$ and Kei YAMADA ${ }^{3}$}

In acidic and ammonia alkaline suspensions of sulphur particles each covered with a CuS layer, a disproportionation reaction, i.e., formation of $\mathrm{CuS}$ from $\mathrm{Cu}^{2+}$ and $\mathrm{Cu}-\mathrm{NH}_{3}$ complex ion, respectively, and concurrent oxidation of $\mathrm{S}$ to form $\mathrm{SO}_{4}$, takes place at appreciable rates. The former is considered to be a cathodic reaction, while the latter an anodic reaction; for example, $\mathrm{Cu}^{2+}+\mathrm{S}+2 \mathrm{e}=\mathrm{CuS}(1)$ and $\mathrm{S}+4 \mathrm{H}_{2} \mathrm{O}=\mathrm{SO}_{4}{ }^{2-}+8 \mathrm{H}^{+}+6 \mathrm{e}(2)$, respectively. For eq. (1) data of sulphidising suspension electrolysis show that the rate is very rapid. This is indicative of eq. (2) being the rate-determining step. The current density $i$ for the anodic reaction can, therefore, be calculated from the reaction rate and the total surface area of sulphur. The current densities for both acidic and ammonia alkaline suspensions are discussed as a function of the suspension potential $E_{m}(\mathrm{SCE})$ and $\mathrm{pH}$. It then is found that $i$ is represented by

$$
i=\text { const. }\left[\mathrm{H}^{+}\right]^{-m} \exp \left[\frac{0.87 F}{R T}\left(E_{m}-E_{0}\right)\right]
$$

where $m$ is a pH-dependent constant and $E_{0}$ a tentative equilibrium electrode potential.

Sulphur in synthetic $\mathrm{CuS}$ is oxidized to form $\mathrm{SO}_{4}$ at controlled suspension potentials of $0.34 \sim 0.36 \mathrm{~V}$ and to form $\mathrm{S}$ at $0.42 \sim 0.55 \mathrm{~V}$, while that in oxidation residue of $\mathrm{Pb}$ concentrate to form $\mathrm{SO}_{4}$ at $0.25 \sim 0.45 \mathrm{~V}$. The current densities of these $\mathrm{SO}_{4}$-forming reactions are the same order. Explanations are given for the effects of the $\mathrm{pH}$ and temperature on the S-forming and $\mathrm{SO}_{4}$-forming reactions for oxidation of metal sulphide. Data for precipitation of $\mathrm{CuS}$ with $\mathrm{S}$ in acidic solution under $\mathrm{SO}_{2}$ pressure are compared with the results obtained. It seems that the oxidation rate of $\mathrm{SO}_{2}$ to $\mathrm{SO}_{4}$ is about $10^{5}$ times faster than that of $S$.

(1. Dr., Process Metallurgy Div., Natl. Research Inst. Metals.

2. Process Met. Div., NRIM.)

3. Metallurgical Chem. Div., NRIM. 